Avian Pathology

\title{
Susceptibility of different strains of pigeon herpesvirus to trisodium phosphonoformate
}

\author{
Anne Schwers , H. Vindevogel , P. Leroy \& P.P. Pastoret
}

To cite this article: Anne Schwers , H. Vindevogel , P. Leroy \& P.P. Pastoret (1981) Susceptibility of different strains of pigeon herpesvirus to trisodium phosphonoformate, Avian Pathology, 10:1, 23-29, DOI: $10.1080 / 03079458108418455$

To link to this article: https://doi.org/10.1080/03079458108418455

曲 Published online: 12 Nov 2007.

Submit your article to this journal

Џ Article views: 80

Citing articles: 6 View citing articles $\longleftarrow$ 


\title{
SUSCEPTIBILITY OF DIFFERENT STRAINS OF PIGEON HERPESVIRUS TO TRISODIUM PHOSPHONOFORMATE
}

\author{
ANNE SCHWERS, H. VINDEVOGEL, P. LEROY \\ and P.P. PASTORET \\ Faculty of Veterinary Medicine, University of Liège \\ 45 rue des Vétérinaires, $B-1070$ Brussels, Belgium
}

\begin{abstract}
SUMMARY
The susceptibility to trisodium phosphonoformate of five strains of pigeon herpesvirus (Pigeon Herpesvirus 1, PHV) was compared by measuring the mean plaque size variations in the presence of different concentrations of the compound.
\end{abstract}

Significant differences in their susceptibility to phosphonoformate were observed, but none of them was found to be naturally resistant. This finding may be of significance for a possible clinical application in the treatment of pigeon herpesvirus infection.

\section{INTRODUCTION}

Disodium phosphonoacetate and trisodium phosphonoformate are recently discovered antiherpetic compounds which are slightly cytotoxic and exhibit an important antiviral effect due to a specific inhibition of the herpesvirus-induced DNA-polymerase (Overby et al., 1974; Mao and Robishaw, 1975; Helgstrand et al., 1978). A possible mechanism of inhibition is an interference with a pyrophosphate binding site on the polymerase (Öberg and Helgstrand, 1978; Helgstrand and Öberg, 1978).

Susceptibility to these two compounds has been reported for all the herpesviruses so far studied, for instance turkey herpesvirus (Turkey Herpesvinus 1, HVT), Marek's disease virus (Phasianid Herpesvinus 2, MDV) (Lee et al., 1978; Reno et al. , 1978) and pigeon herpesvirus (Pigeon Herpesvirus 1, PHV) (Schwers et al, 1980). Some strains of several herpesviruses were found to be resistant (Jofre et al., 1977; Duff et al. 1978; Reno et al., 1978).

For therapeutic purpose, the use of phosphonoacetate is limited because of its topical irritative potential (Kern et al. , 1978), its toxicity for laboratory animals and its accumulation in bones (Bopp et al, 1977). Phosphonoformate does not irritate the skin or the mucous membranes, and has been successfully used for the treatment of experimental cutaneous and ocular herpes simplex type 1 (Human Herpesvinus 1, HSV1) infection (Alenius et al, , 1978; Oberg et al., 1978) or genital infection of guinea pigs 
with herpes simplex type 2 (Human Herpesvinus 2, HSV2) (Alenius and Nordlinder, 1979). Furthermore, phosphonoformate has only minor effects on normal cellular metabolism (Stenberg and Larsson, 1978).

The present report deals with the comparison between the susceptibility of several strains of pigeon herpesvirus to phosphonoformate by measuring the effect of this compound on the mean size of plaques produced under agarose overlay. This investigation was performed with a view to a possible clinical application for the treatment of local lesions produced by PHV.

\section{MATERIALS AND METHODS}

\section{Viruses}

Two strains of $\mathrm{PHV}\left(\mathrm{PHV} / \mathrm{B} / \mathrm{Cu}_{2}\right.$ and $\left.\mathrm{PHV} / \mathrm{B} / \mathrm{Cu}_{3}\right)$ were isolated in our laboratory at Brussels (Cureghem) from young pigeons (Vindevogel and Duchatel, 1978), and a third one from psittacine birds (PHV/Psi/B/Cu) (Vindevogel et al., 1978; Vindevogel, et al. 1980).

A strain of PHV isolated in Czechoslovakia (PHV/Cz/V 236/69) (Krupiðka et al., 1970) was kindly provided by Dr. Smíd (Veterinary Research Institute, Hudcova), and another one isolated in Australia (PHV/A/B 50) (Boyle and Binnington, 1973) was obtained from Dr. Simmons (Animal Research Institute, Queensland).

\section{Cell cultures}

Chicken embryo fibroblasts (CEF) were cultured as previously described (Vindevogel et al. 1975).

\section{Production of plaques}

Confluent cell monolayers, grown in Petri dishes (plastic Falcon; $30 \mathrm{~mm}$ diam.) were inoculated with $0.2 \mathrm{ml}$ of 10 -fold viral dilutions. After 1 hour of adsorption, the infected cells were covered with Minimum Essential Medium (MEM) containing 1\% agarose (indubiose) and $2 \%$ foetal bovine serum. This overlay medium was supplemented with trisodium phosphonoformate at the following final concentrations: 10 and $100 \mu \mathrm{M} / \mathrm{ml}$. As controls, the same procedure was followed on uninfected cells and inoculated cells were incubated with maintenance medium devoid of phosphonoformate.

All the experiments were done on the same day, in the same CEF culture and with the same medium.

The cells were fixed with formaldehyde after 4 days of incubation, then stained with May-Grünwald Giemsa (Vindevogel et al., 1975).

The experiments were twice repeated.

\section{Measurement of mean plaque size}

Cell cultures inoculated with the optimal viral dilution, causing a sufficient number of isolated plaques, were examined according to a method previously described (Jetteur et al., 1979; Pastoret et al., 1979; Schwers et al., 1980).

Briefly, plaques were printed with an offset camera to obtain a final magnification of $x 20$. For each virus at each concentration of phosphonoformate, the areas of 50 plaques taken at random were measured with an $\mathrm{OH}$ Kempton planimeter.

\section{Statistical tests}

Normality test. The normality of the plaque size distribution was studied by skewness and kurtosis tests. 
Analysis of variance. The effect of the addition of trisodium phosphonoformate at increasing concentrations in the medium was studied by a one-way analysis of variance.

Student's t-test was used to determine which concentrations of phosphonoformate were producing a significant reduction of the plaque size.

Interaction test. To see if the susceptibility to phosphonoformate was the same for each strain, a two-way analysis of variance was performed and the hypothesis of absence of interaction was tested by the F-test.

\section{RESULTS}

The mean of the plaque size for PHV is given in Table 1.

Table 1. Mean plaque size of PHV strains.

\begin{tabular}{|l|l|c|c|}
\hline \multirow{2}{*}{\multicolumn{1}{|c|}{ Strains }} & \multicolumn{3}{|c|}{$\begin{array}{c}\text { Mean plaque size at different concentrations } \\
(\mu \mathrm{M} / \mathrm{ml}) \text { of phosphonoformate }\end{array}$} \\
\cline { 2 - 4 } & 0 & 10 & 100 \\
\hline $\mathrm{PHV} / \mathrm{B} / \mathrm{Cu}_{2}$ & $0.7627^{\mathrm{a}}$ & 0.5432 & 0.1316 \\
$\mathrm{PHV} / \mathrm{B} / \mathrm{Cu}_{3}$ & 0.4438 & 0.2331 & 0.1910 \\
$\mathrm{PHV} / \mathrm{Psi} / \mathrm{B} / \mathrm{Cu}$ & 0.5644 & 0.4769 & 0.2135 \\
$\mathrm{PHV} / \mathrm{Cz} / \mathrm{V} \mathrm{236/69}$ & 0.5160 & 0.2910 & 0.1157 \\
$\mathrm{PHV} / \mathrm{A} / \mathrm{B} \mathrm{50}$ & 0.4800 & 0.3452 & 0.1621 \\
\hline
\end{tabular}

a Values are given in $\mathrm{mm}^{2}$ and calculated from 50 plaques.

\section{Normality test}

The sizes of the plaque population produced by PHV strains were not quite normally distributed in the presence of phosphonoformate. The square root of the plaque size always followed a normal distribution, thus allowing variance analysis.

\section{Analysis of variance}

Addition of phosphonoformate induced a marked reduction of the mean plaque size $(P<0.001)$ for each of the five strains studied.

By use of the t-test, a significant reduction of the mean plaque size with each concentration of trisodium phosphonoformate $(10,100 \mu \mathrm{M} / \mathrm{ml})(P<0.02)$ was found, except for $\mathrm{PHV} / \mathrm{B} / \mathrm{Cu}_{3}$ and $\mathrm{PHV} / \mathrm{Psi} / \mathrm{B} / \mathrm{Cu}$ strains. Indeed, the addition of more than $10 \mu \mathrm{M} / \mathrm{ml}$ phosphonoformate in the presence of $\mathrm{PHV} / \mathrm{B} / \mathrm{Cu}_{3}$ did not induce a further reduction in the mean size; for $\mathrm{PHV} / \mathrm{Psi} / \mathrm{B} / \mathrm{Cu}$ we did not observe a significant reduction of the plaque size after addition of $10 \mu \mathrm{M} / \mathrm{ml}$ of phphonoformate, but we did so after the addition of $100 \mu \mathrm{M} / \mathrm{ml}$ (Text-fig.1).

Comparison between the strains by their mean plaque size reduction in the presence of phosphonoformate

Significant differences were observed between the strains from the point of view of mean plaque size reduction in the presence of phosphonoformate $(P<0.001)$. All the strains studied differed from each other on the basis of the determination of their reduction rate in the presence of 10 or $100 \mu \mathrm{M} / \mathrm{ml}$ of phosphonoformate (Text-fig.1). The most susceptible strain was PHV/Cz/V 236/69, followed by $\mathrm{PHV} / \mathrm{B} / \mathrm{Cu}_{2}, \mathrm{PHV} / \mathrm{A} / \mathrm{B} 50$ and $\mathrm{PHV} / \mathrm{B} / \mathrm{Cu}_{3} ; \mathrm{PHV} / \mathrm{B} / \mathrm{Cu}_{3}$ was less susceptible than the other strains at high concentrations, whereas $\mathrm{PHV} / \mathrm{Psi} / \mathrm{B} / \mathrm{Cu}$ was the least susceptible. A second experiment gave similar results. 


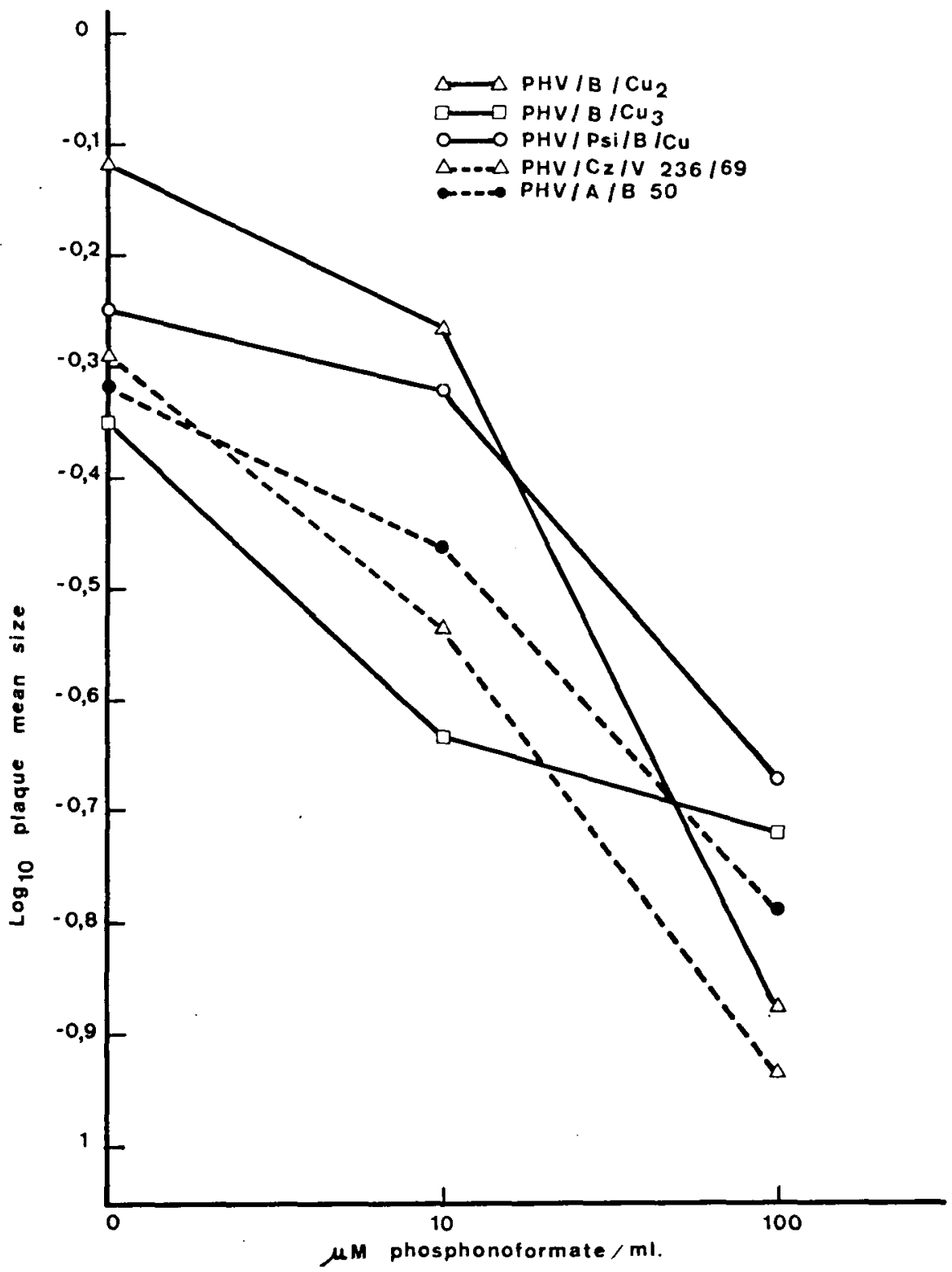

Text-fig.1. Comparison between the mean plaque size reduction of PHV strains with increasing concentrations of trisodium phosphonoformate. 


\section{DISCUSSION}

All the PHV strains studied were susceptible to trisodium phosphonoformate. In fact, the mean plaque size of the different PHV strains was reduced in the presence of phosphonoformate and, by comparing their reduction rate, it can be shown that each strain differs from any other according to its susceptibility to the compound. This agrees with the observations of Reno et al. (1978) who described variations between several strains of HVT in their susceptibility of phosphonoformate, some of them being resistant.

The strain isolated from psittacines was less susceptible than the other strains although it was a typical PHV strain (Vindevogel et al., 1980).

It remains to be studied whether these differences within the same viral species are as important as those between two different species (Schwers et al., 1980).

The finding that there are differences between several strains of PHV in the presence of phosphonoformate may be important from the point of view of a possible clinical application in the treatment of local lesions produced by PHV infection, notwithstanding the fact that none of the PHV strains studied was found to be naturally resistant to the compound.

\section{Acknowledgements}

We wish to thank Dr. B. Öberg (Astra Häkemedel AB, Sweden) for providing us with trisodium phosphonoformate, Dr. Smíd (Veterinary Research Institute, Hudcova, Czechoslovakia) and Dr. Simmons (Animal Research Institute, Queensland, Australia) for providing the pigeon herpesvirus strains V 236/69 and B 50.

We also wish to thank Dr. A. Aguilar-Setién, Annick Verheyden and Martine Godart for their help, and Lise Dagenais for revising the manuscript.

\section{REFERENCES}

Alenius, S., Dinter, Z. and Öberg, B. (1978). Therapeutic effect of trisodium phosphonoformate on cutaneous herpesvirus infection in Guinea pigs. Antimicrobial Agents and Chemotherapy, 14: $408-413$.

Alenius, S. and Nordlinder, H. (1979). Effect of trisodium phosphonoformate in genital infection of female Guinea pigs with herpes simplex virus type 2. Archives of Virology, 60: 197.206.

Bopp, B.A., Estep, C.B. and Anderson, D.J. (1977). Disposition of disodium phosphonoacetate $14 \mathrm{C}$ in rat, rabbit, dog and monkey. Federation Proceedings, 36: 939.

Boyle, D.B. and Binnington, J.A. (1973). Isolation of a herpesvirus from a pigeon. Australian Veterinary Journal, 49: 54.

Duff, R.G., Robishaw, E.E., Mao, J.C. and Overby, L.R. (1978). Characteristics of herpes simplex virus resistance to disodium phosphonoacetate. Intervirology, 9: 193-205.

Helgstrand, E., Eriksson, B., Johansson, N.G., Lannerö, B., Larsson, A., Misiorny, A., Noren, J.O., Sjöberg, B., Stenberg, K., Stening, G., Stridh, S., Öberg, B., Alenius, S. and Philipson, L. (1978). Trisodium phosphonoformate, a new antiviral compound. Science, 201: 819-821.

Helgstrand, E. and Öberg, B. (1978). Antiviral screening based on cell-free polymerase models and a new selective inhibitor. Current Chemotherapy: 329-330.

Jetteur, P., Pastoret, P.P., Aguilar-Setien, A., Leroy, P., Godart, M. and Schoenaers, F. (1979). Différenciation de souches du virus de la rhinotrachéite infectieuse bovine (Bovid Herpesvirus 1) fondée sur la dimension moyenne des plages. Annales de Médecine Vétérinaire, 123: 115-121.

Jofre, J.T., Schaffer, P.A. and Parris, D.S. (1977). Genetics of resistance to phosphonoacetic acid in strain KOS of herpes simplex virus type 1. Journal of Virology, 23: 833-836.

Kern, E.R., Glasgow, L.A., Overall, J.C., Reno, J.M. and Boezi, J.A. (1978). Treatment of experimental herpesvirus infections with phosphonoformate and some comparisons with phosphonoacetate. Antimicrobial Agents and Chemotherapy, 14: 817-823. 
Krupicka, V., Smld, B., Valicek, L. and Pleva, V. (1970). Isolation of a herpesvirus from pigeon on the chorio-allantoic membrane of embryonated eggs. Veterinary Medicine (Praha), 15: 609 .

Lee, L.F., Reno, J.M. and Boezi, J.A. (1978). Effect of phosphonoformate on the replication of Marek's disease virus and phosphonoacetate-resistant mutants. In: Herpesvirus Workshop, Programme and Abstracts, p.30. St. John's College, Cambridge.

Mao, J.C.H. and Robishaw, E.E. (1975). Mode of inhibition of herpes simplex virus DNA polymerase by phosphonoacetate. Biochemistry, 14: 5475-5479.

Öberg, B. and Helgstrand, $E$. (1978). The antiviral activity of trisodium phosphonoformate. In: International Virology IV, Abstracts of the Fourth International Congress for Virology, p.125. Edited by Centre for Agricultural Publishing and Documentation, Wageningen.

Öberg, B., Alenius, S., Eriksson, B. and Helgstrand, E. (1978). Inhibition of herpesvirus multiplication by trisodium phosphonoformate. In: Herpesvirus Workshop, Programme and Abstracts, p.29. St. John's College, Cambridge.

Overby, L.R., Robishaw, E.E., Schleider, J.B., Rueter, N.I., Shipkowitz, N.L. and Mao, J.C.H. (1974). Inhibition of herpes simplex virus replication by phosphonoacetic acid. Antimicrobial Agents and Chemotherapy, 6:360-365.

Pastoret, P.P., Jetteur, P., Aguilar-Setièn, A., Leroy, P., Schwers, A., Godart, M. and Schoenaers, $F$. (1979). Effet de la dexaméthasone sur le titre et la taille des plages du virus de la rhinotrachéite infectieuse bovine (Bovid Herpesvirus 1, IBR). Annales de Médecine Vétérinaire, 123: 397402 .

Reno, J.M., Lee, L.F. and Boezi, J.A. (1978). Inhibition of herpesvirus replication and herpesvirus-induced DNA polymerase by phosphonoformate. Antimicrobial Agents and Chemotherapy, 13:188-192.

Schwers, A., Pastoret, P.P., Vindevogel, H., Leroy, P., Aguilar-Setién, A. and Godart, M. (1980). Comparison of the effect of trisodium phosphonoformate on the mean plaque size of pseudorabies virus, infectious bovine rhinotracheitis virus and pigeon herpesvirus. Journal of Comparative Pathology, 90: 625-633.

Stenberg, $K$. and Larsson, $A$. (1978). Reversible effect on cellular metabolism and proliferation by trisodium phosphonoformate. Antimicrobial Agents and Chemotherapy, 14: 727-730.

Vindevogel, H., Pastoret, P.P., Burtonboy, G., Gouffaux, M. and Duchatel, J.P. (1975). Isolement d'un virus herpès dans un élevage de pigeons de chair. Annales de Recherches Véterinaires, 6: 431-436.

Vindevogel, $H$. and Duchatel, J.P. (1978). Contribution à l'étude de l'étiologie du coryza infectieux du pigeon. Annales de Médecine Vétérinaire, 122: 507-513.

Vindevogel, H., Duchatel, J.P. and Burtonboy, G. (1978). Infection herpétique de psittacidés. Annales de Médecine Vétérinaire, 122: 167.

Vindevogel, H., Pastoret, P.P., Leroy, P. and Coignoul, F. (1980). Comparaison de trois souches de virus herpétique isolées de psittacidés avec le virus herpès du pigeon. Avian Pathology, 9: 385-394.

\section{RESUME}

\section{Etude la sensibilité de différentes souches de virus Herpès} du pigeon au phosphonoformate de sodium

La sensibilité au phosphonoformate de sodium de cinq souches de virus herpès du pigeon (Pigeon Herpesvirus 1, PHV) a été étudiée en comparant les variations de la surface des plages liées aux différentes concentrations du produit.

Les cinq sou ches montrent des sensibilités différentes au phosphonoformate, mais aucune d'entre elles n'y est naturellement résistante. Ces résultats sont encourageants pour une utilisation clinique du phosphonoformate dans le traitement de l'infection herpétique du pigeon. 


\section{ZUSAMMENFASSUNG}

\section{Die Empfindlichkeit verschiedener Taubenherpes- virusstämme gegen Trinatriumphosphonoformat}

Die Empfindlichkeit von fünf Stämmen des Taubenherpesvirus (Taubenherpesvirus 1, PHV) gegen Trinatriumphosphonoformat wurde durch Messungen der Größenvariationen der Plaques in Gegenwart verschiedener Konzentrationen dieser Substanz vergleichend untersucht.

Es wurden signifikante Unterschiede in der Empfindlichkeit gegenüber Phosphonoformat beobachtet, aber keinerlei natürliche Resistenz. Dieses Ergebnis könnte bei einer evtl. klinischen Anwendung zur Behandlung der Taubenherpesvirus-Infektion von Bedeutung sein. 